\title{
Ethnic Tolerance Among Students in Malaysian Public Universities
}

\author{
Nur Farahana ZULKERNAIN, Wan Norhasniah WAN HUSIN* \\ Department of Strategic Studies, Faculty of Defence and Management Studies \\ National Defence University of Malaysia, Sungai Besi Camp \\ Kuala Lumpur, Malaysia,
}

${ }^{*}$ Corresponding author

Keywords: Tolerance; Ethnic Tolerance; Public Universities; Students.

\begin{abstract}
The main objective of this study is to determine the level of ethnic tolerance among students in Malaysian public universities. The study involved 378 respondents from three public research universities and represented by three major ethnics, the Malays, Chinese and Indians. The research utilized quantitative method and the data were collected through a set of questionnaire, based upon ethnic tolerance concept developed by past researchers. The data was analyzed using the Statistical Package for the Social Sciences (SPSS) software version 22. The findings reveal that in general the level of tolerance among the students is satisfactorily high. Meanwhile, the Malay students were found to have the tolerant level of $83.0 \%$, followed by the Indians with $71.4 \%$, and the Chinese with $67.5 \%$.
\end{abstract}

\section{Introduction}

The spirit of ethnic tolerance in Malaysia was found to have declined over the years, starting from the end of 1990s [1]. The major reason for the notorious ethnic riots in 13 May 1969 was the strained ethnic ties due to the competing political and economic demands by the different ethnics [2]. Then, the conflicts unfortunately continued due to several incidents, like the use of the term "Allah" by non-Muslims and attacks upon religious houses [3]. The strain was due to the diversities in backgrounds of culture, religion, and political and economic demands. Based on those incidents, it was quite obvious that ethnic tolerance was declining and jeopardizing national peace and harmony.

Practicing the value of tolerance is not something new as it has been practiced by other countries and past leaders. The awareness on the importance of establishing understanding among the members of society, had spurred some leaders to instill the spirit of tolerance in their countries. For example, the leaders of United Arab Emirates (UAE) established the Ministry of Tolerance in February 2016 with the aim of reinforcing cooperation and assisting individuals to understand the interethnic relationship, and the services that could be rendered to the community and country [4]. A similar scenario was adopted by the United Nations (UN) which have acknowledged 16 November as the International Day of Tolerance with the aim of ensuring that every individual receives the respect they deserved and appreciates the various cultures in their own countries [5]. In fact, the practice of tolerating others was also nurtured by Malaysian leaders in their efforts to achieve independence as demonstrated by Tunku Abdul Rahman who surrendered some of United Malays National Organization's (UMNO) parliamentary seats to the Chinese and Indian communities in efforts to coerce them to participate in the 1955 Federal Elections. Meanwhile, the Malayan Chinese Association (MCA) leader, Tan Cheng Lock also displayed some goodwill by retracting the demand to implement the Chinese language as one of the national languages. The action was aimed at promoting racial harmony and peace and seeking the independence of the Federation of Malaya [6].

Hence, in the context of Malaysian pluralistic society, with the aim of maintaining racial harmony and unity, the government had emphasized upon the cultivation of the value of tolerance among every ethnic community. It is apparent that by enforcing the spirit of tolerance, the government had succeeded in maintaining political, economic and social stability that allowed 
Malaysia to develop into a nation with a stable economy. In fact, Malaysia was also listed as the 30th most peaceful nation in the world [7]. To ensure that the value of tolerance was observed in the plural society, it was determined that the Higher Learning Institutions (HLIs) would be the excellent platform to meet the objectives. This is because, based on the slogan Vision 2020 visualized by the fourth Prime Minister Malaysia Dr. Mahathir Mohamad, HLIs were regarded as the best place to foster the spirit of patriotism and a caring community by instilling noble values like respecting others, and tolerance among the students [8]. The presence of various ethnic communities in educational institutions, whether in schools or universities, is expected to foster the spirit of tolerance during the interaction process. As a result of continuous interaction processes, indirectly, understanding and awareness about cultural background, religion and language would be prevalent in every segments of the societies [9].

Either in schools or HLIs, learning about the early history of the land, its various culture, religion, tradition, language and the status of the different ethnic communities could be explained by teachers and lecturers during lessons and social interaction either between teachers or students, conducted indirectly as it will reduce the feeling of prejudice and misconception, thus enhancing the spirit of tolerance. Through education, the value of tolerance could be nurtured effectively through the socialization process which nurtures the feeling of respect. Furthermore, the subject of Ethnic Relations was introduced at Malaysian public universities with the aim of increasing understanding among the different ethnics and to improve the students' awareness. The government's efforts to improve the education system by cultivating their mind set to be tolerant towards others, was a mechanism to nurture them into becoming responsible youths and citizens that are respectful towards people from different ethnicity [10]. Based on the efforts to improve ethnic unity, and maintaining peace and harmony of the nation, the study aims to analyze the level of tolerance among students in Malaysia public universities by focusing on the three main ethnic communities the Malays, Chinese and Indians.

\section{Material and Methods}

This research employed exploratory and cross-sectional design in order to conduct initial research to clarify and determine the focus of the research systematically among student in HLIs in Malaysia. A set of questionnaire as the instrument to collect a considerably large amount of quantitative data was used as an appropriate instrument as it is an effective and cost-saving method in the process of data compiling [11]. The questionnaire was constructed by adapting and modifying based on past previous research on ethnic tolerance study. The content validity was conducted and been revised by several experts from various fields which are ethnic relation studies, quantitative method and statistics experts. Following that, a back translation technique was utilized to increase the validity of the research findings by converting all Malay questions version into English question version [12]. A pilot test was conducted to test the reliability of the questionnaire for the actual survey on 30 respondents from Universiti Putra Malaysia (UPM). By using Statistical Package for the Social Sciences (SPSS) software version 22, the reliability test was tested and the Alpha Cronbach value showed satisfying result to carry out this research.

The set of questionnaire contains two parts which are the demographic and the ethnic tolerance section, measured using the 5-point Likert-scale that are within the range of 1 - strongly disagree, 2 - disagree, 3 - undecided, 4 - agree and 5 - strongly agree. The questionnaire was adapted from Nazri and Mansor (2014) to identify the level of ethnic tolerance among public university students. This research used stratified random sampling method which is suitable and accurate for a large number of populations with subgroups in order to achieve the sampling purpose. 378 respondents were chosen from three universities that are Universiti Malaya (UM), Universiti Kebangsaan Malaysia (UKM) and Universiti Putra Malaysia (UPM), to ensure that the chosen respondents represented the total population (refer to Table 1). The ratio 6:3:1 (refer to Table 1) was also used in the research to represent the Malaysian ethnic community in whole, that are the Malays, Chinese and Indians [13]. 
Table 1. Total number of respondents

\begin{tabular}{l|c|c|c|c}
\hline \multicolumn{1}{c|}{ University } & \multicolumn{2}{c|}{$\begin{array}{c}\text { Total Number } \\
\text { of Respondents }\end{array}$} & \multicolumn{3}{c}{ Total Number of Students based on Ethnic } \\
Breakdown
\end{tabular}

The collected data were analyzed using the SPSS software version 22 to determine the reliability testing and cross-tabular analysis. Based on the reliability test, Cronbach Alpha result for ethnic tolerance is more than the value of 0.7 , indicating that the reliability was acceptable [14]. Based on the overall mean score for the level of ethnic tolerance, the mean scores were categorized into three parts that are low, moderate and high to interpret the mean score since the scales used in the questionnaires were five scales. This interpretation scale will be used to discuss the level of ethnic tolerance in this research [15]. The mean score interpretation was shown in Table 2.

Table 2. Mean Score Interpretation Scale

\begin{tabular}{c|c}
\hline Level & Mean Score Interpretation Scale \\
\hline Low & $1.00-2.33$ \\
\hline Moderate & $2.34-3.67$ \\
\hline High & $3.68-5.00$ \\
\hline
\end{tabular}

\section{Results}

\section{Respondents' demographics}

Out of a total of 378 respondents, 125 respondents (33.1\%) were from UM, 125 respondents were from UKM (33.1\%) and respondents from UPM were 128 (33.9\%). Most of the respondents were Malays with 229 respondents $(60.6 \%)$, followed by the Chinese with 114 respondents $(30.2 \%)$, and followed by the Indians with 35 (9.3\%). Meanwhile, there were 229 Muslim respondents (60.6\%), followed by 51 Buddhist respondents (13.5\%), and 2 Taoist respondents $(0.5 \%)$. Then there were 31 Hindu respondents $(8.2 \%)$, followed by 58 Christian respondents $(15.35)$, and 7 respondents from other religions $(1.9 \%)$. The majority of the respondents, $117(31.0 \%)$ lived in cities, followed by 107 respondents $(28.3 \%)$ that were from villages, and 105 respondents $(27.8 \%)$ that resided in small towns. Only a small number of respondents, 49 (13.0\%) lived in town districts. The findings showed that there was a stark difference between students who had friends from different ethnics, with students who had taken part and those who did not participate much in community activities. The results indicate that, most students who participated in community activities had more friends from different ethnicities. 120 respondents (31.7\%) had many friends from different ethnics, followed by 187 respondents $(49.5 \%)$ with few friends from different ethnics. Meanwhile, a total of 71 respondents $(18.8 \%)$ disclosed that they had no friends from different ethnics.

\section{Respondents' perception of ethnic tolerance}

Table 3 shows the public university students' perception of ethnic tolerance. Most of the respondents agreed and determined that the respondents have high level of perception on ethnic tolerance. The statement of highest level for "The existence of different vernacular schools is unique" shows the highest level $(94.4 \%)$, followed by "I am ready to mingle with an individual from another ethnic" (89.2\%), "My friends from a different ethnic and I use Bahasa Malaysia when we interact" (83.1\%), "I can eat with people from other ethnics" (82.6\%), "I can discuss about ethnic relation issues" ( $81.7 \%)$, "I am comfortable to share business with people from different ethnics" (77.5\%), "I watch TV programs hosted by a person from a different ethnic" (77.2\%) and "I 
accept mixed marriages" $(67.5 \%)$. Even though the majority of the respondents are at a high level of ethnic tolerance, however, surprisingly, there are some slightly over one-third of the undergraduates $(23.3 \%)$ admitted that they could not accept mixed marriages.

Table 3. Respondents' Perception of Ethnic Tolerance

\begin{tabular}{l|c|c|c}
\hline \multicolumn{1}{c}{ Item } & \multicolumn{3}{c}{ Level } \\
\hline & \multicolumn{1}{c}{$\begin{array}{c}\text { Low } \\
f(\%)\end{array}$} & $\begin{array}{c}\text { Moderate } \\
f(\%)\end{array}$ & $\begin{array}{c}\text { High } \\
f(\%)\end{array}$ \\
\hline $\begin{array}{l}\text { I am comfortable to share business with people from } \\
\text { different ethnics }\end{array}$ & $73(19.3)$ & $12(3.2)$ & $293(77.5)$ \\
\hline $\begin{array}{l}\text { I am ready to mingle with an individual from another } \\
\text { ethnic }\end{array}$ & $38(10.1)$ & $3(0.8)$ & $337(89.2)$ \\
\hline I can eat with people from other ethnics & $10(2.6)$ & $55(14.6)$ & $313(82.6)$ \\
\hline I accept mixed marriages & $88(23.3)$ & $35(9.3)$ & $255(67.5)$ \\
\hline I can discuss about ethnic relation issues & $49(13.0)$ & $20(5.3)$ & $309(81.7)$ \\
\hline $\begin{array}{l}\text { My friends from a different ethnic and I use Bahasa } \\
\text { Malaysia when we interact }\end{array}$ & $40(10.6)$ & $24(6.3)$ & $314(83.1)$ \\
\hline $\begin{array}{l}\text { I watch TV programs hosted by a person from a } \\
\text { different ethnic }\end{array}$ & $60(15.9)$ & $26(6.9)$ & $292(77.2)$ \\
\hline The existence of different vernacular schools is unique & $17(4.5)$ & $4(1.1)$ & $357(94.4)$ \\
\hline
\end{tabular}

\section{Level of ethnic tolerance}

In Table 4, the five dimensions of ethnic tolerance that are acknowledging, comfortable, accepting, sharing and proud, it was established that the level of ethnic tolerance among university students was at a moderately high level of $77.2 \%$ Malay university students were the most tolerant (83.0\%), followed by the Indians (71.4\%) and Chinese (67.5\%).

Table 4. Level of Ethnic Tolerance

\begin{tabular}{l|c|c|c}
\hline \multicolumn{1}{c|}{ Category } & \multicolumn{3}{|c}{ Level } \\
\hline & Low & Moderate & High \\
\hline All Students & $f(\%)$ & $f(\%)$ & $f(\%)$ \\
\hline Malay & $34(9.0)$ & $52(13.8)$ & $292(77.2)$ \\
\hline Chinese & $0(0.0)$ & $39(17.0)$ & $190(83.0)$ \\
\hline Indian & $25(21.9)$ & $12(10.5)$ & $77(67.5)$ \\
\hline
\end{tabular}

\section{Summary and Discussion}

The research findings reveal that university students from the Malay ethnic community are the most tolerant. The factor could be due to the core Budi-Islam values embedded into the Malay soul, that stress upon three main values that are way of speech, conduct/manners and language that play a role in influencing the spirit of tolerance among the Malays. Meanwhile, the findings also highlight that the Chinese and Indians were marginally less tolerant as the Malays, which could be due the inherited cultural foundation values of the ethnics [2]. Other from the cultural factor, the fostering of the spirit of tolerance among the university students could also be influenced by their participation in communal activities. Even though past researchers indicated that most of the minority communities are more tolerant compared to Malay communities, but the results shows that the high level of tolerance are more focusing on the political aspect which are contradict with this research. Overall, the research findings established that the majority of public university students from the three ethnics recorded a high level value of tolerance. The reinforcement of the tolerance value also involved government efforts that made it compulsory for university students to take up the Ethnic Relations subject. 


\section{Acknowledgement}

We wish to offer our gratitude for the opportunity extended by FRGS/1/2015/SS10/UPNM/02/1, Fundamental Research Grant Scheme (FRGS) 2015.

\section{References}

[1] S.S., Faruqi, The Bedrock of Our Nation: Our Constitutions. Kuala Lumpur: Zubedy Ideahouse, 2012, pp. 45-55.

[2] W.N. Wan Husin, Peradaban dan Perkauman di Malaysia: Hubungan Etnik Melayu-Cina (Civilization and Communalism in Malaysia: Ethnic Relation between Malays-Chinese). Universiti Malaya, Kuala Lumpur, 2012.

[3] M.N. Mohd Roslan, Religious Tolerance in Malaysia: An Overview. Middle-East Journal of Scientific Research 9(1), 2011, pp. 23-27.

[4] United Arab Emirates, UAE Annual Book 2016, National Media Concil, UAE, 2016.

[5] United Nations, International Day for Tolerance: 16 November. Information on http://www.un.org/en/events/toleranceday/index.shtml

[6] W.N. Wan Husin. Inter-Ethnic Tolerance and Communalism in Pre-Independence Malaysia. The European Proceedings of Social \& Behavioral Sciences 21, 2017, pp. 123-132.

[7] B, Shamsul Amri, Many Ethnicities, Many Cultures, One Nation: The Malaysian Experience. UKM Ethnic Studies Paper Series 2, 2008, pp. 9-30.

[8] I. Fazilah, Y. Mashitoh, Mohamad Taha, Teaching and Learning Methods of Ethnic Relations Course: Interactive or Destructive? Procedia Social and Behavioral Sciences 59, 2012, pp. 105-109.

[9] Abdul Razaq, Ahmad Ali, Diversity as a Medium to Reinforce Ethnic Tolerance in History Subject in Malaysia. International Journal of Academic Research in Business and Social Sciences 2(12), 2012, pp. 317-326.

[10] B. Shamsul Amri, Menguruskan "Ketegangan Yang Stabil": Hubungan Etnik di Malaysia Diteliti Semula (Managing "Stable Tension". Revisited Ethnic Relations in Malaysia), in: Khazanah Nasional (Eds.). Himpunan Esei Pembangunan (Collection of Development Essay): Malaysia 2057, Khazanah.

[11] D. Wilkinson, P. Birmingham, Using Research Instruments: A Guide for Researchers, Routledge Falmer, London, 2003.

[12] U. Sekaran, R. Bougie, Research Methods for Business: A Skill Building Approach, sixth ed., John Wiley \& Sons Ltd, United Kingdom, 2013.

[13] M. Nazri, K. Mohd Arip, S. Abdul Latif, M. Zulkifli \& H. Zaharah, Student's Perception towards Malay Provision in the Federal Constitution in the Context of Ethnic Relationship in Malaysia. Research Journal of Applied Science 7(3), 2012, pp. 165-176.

[14] J.C. Nunally, Psychometric Theory, second ed., McGraw-Hill, New York, 1978.

[15] I. Fazilah, The Influence of Individual Attributes on Inter-Ethnic Tolerance among Early Youth in Selangor, PhD Dissertation, Universiti Putra Malaysia, Selangor, 2008. 